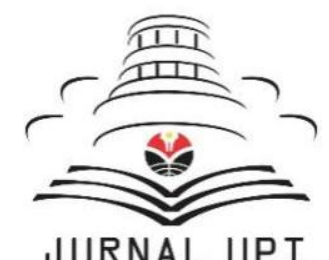

JOURNAL OF APPLIED FOOD AND NUTRITION

Volume 1 Nomor 1, June 2020, 24-29

Available online at:

https://ejournal.upi.edu/index.php/JAFN

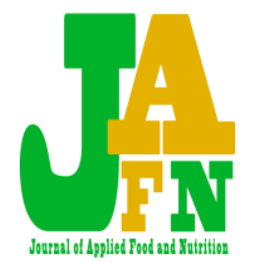

\title{
Description of Diet Patterns in Young Women at SMAN 24 Bandung
}

\author{
Andria Pragholapati ${ }^{1 *}$, Seliana Dwi Rahmawati ${ }^{2}$, Titin Mulyati ${ }^{3}$ \\ ${ }^{1}$ Universitas Pendidikan Indonesia, Jl. Dr. Setiabudhi No. 229, Bandung 40154, Indonesia \\ ${ }^{2}$ Universitas Bhakti Kencana, Bandung, Indonesia \\ ${ }^{3}$ Rumah Sakit Hasan Sadikin, Bandung, Indonesia \\ *Corresponding Author. E-mail: andria.pragholapati@upi.edu
}

\begin{abstract}
A B S T R A C T S
This research is motivated by the large number of young women who often experience dissatisfaction with their body shape, this is because at puberty the appearance of fat in several parts of the body causes disproportionate perceptions of the body. For this reason, many young women go on unhealthy diets to get instant results. According to data from UKS at SMAN 24 Bandung, many students who entered the UKS were due to weakness, gastritis, and even fainting. When a study of the phenomenon was carried out on 10 female students at SMAN 24 Bandung, 9 students admitted that they were dissatisfied with their bodies and were on a diet. The purpose of this study was to determine the relationship between body image and dietary patterns in young women at SMAN 24 Bandung in 2015. The research method used is quantitative with quantitative descriptive types. The sample in this study were 86 students at SMAN 24 Bandung, which were obtained by purposive sampling and stratified random sampling techniques. Data collection using a questionnaire in the form of a Likert scale. The data that has been collected is analyzed using descriptive analysis techniques (univariate. The results of statistical tests show that most young women have an unhealthy diet $(54.7 \%)$. It is recommended that health services should be able to facilitate a counseling program in the form of seminars and discussions for adolescents to examine more deeply about dietary patterns in order to provide the needed solutions.
\end{abstract}

\begin{tabular}{l}
\hline \multicolumn{1}{c}{ A R T I C L E I N F O } \\
\hline Article History: \\
Received May 2020 \\
Revised May 2020 \\
Accepted June 2020 \\
Available online June 2020 \\
Keywords: \\
Diet; Food; Nutrition; \\
Adolescent
\end{tabular}




\section{Introduction}

Adolescence is an important time to adopt health-relevant behaviors. Many of the behaviors associated with ill health and premature death that occur in adults begin in adolescence. In adolescence many individuals attain levels of health, strength, and energy that they will never enjoy at later stages of life. They also have the belief of being unique and immune who will never get sick, or if they get sick, they will quickly recover. With this physical strength and cognitive deception, it is not surprising that there are many adolescents who develop habits that are bad for their health (Santrock, 2007: 279).

In their teens, many of them try to change their appearance so that they look attractive. According to Papalia (2011), concern for the appearance and ideal body image can lead to obsessive efforts such as controlling body weight. This pattern is more common in girls than boys. In adolescent girls, weight and body shape issues are very important and have a strong relationship with body dissatisfaction, diet, and low self-esteem. According to Hurlock, only a few adolescents experience body catexis or feel satisfied with their bodies. This is due to the physical changes in adolescents that occur due to puberty. During puberty, young girls experience physical changes, one of which is increasing fat on the hips, thighs, buttocks and breasts (Jarvis, 2009).

Eating disorders often appear during adolescence or young adulthood, but can also develop during childhood or later in life (National Institute of Mental Health, 2006). The US Census Bureau, International Data Base found the prevalence of individuals with eating behavior deviations in Indonesia of 1,667,170 from an estimated population of 218,451,952 people. Based on a study in Jakarta conducted on young women in SMA 70, it shows that $99.3 \%$ of adolescent girls who are dieting experience a tendency to eat deviations (Kurnia, 2008, in Andea, 2010).

Body image or body image is one of the determinants of social life and the future. Entering the $90 \mathrm{~s}$, women began to be preoccupied with forming an attractive image of themselves in their social environment. According to Cash \& Pruzinsky (2011), body image refers to the psychological experience of a variety of manifestations, the main but not exclusively one physical appearance of a person. Body image for adolescents is an important thing, because during adolescence a person experiences many changes, both physically and psychologically. Changes like this will cause various responses in the form of behavior that is very concerned about changes in body shape. But in getting the ideal body, many teenage girls have unhealthy diets. Currently, the diet is one of the most popular ways to lose weight because the diet can be done by almost everyone, is inexpensive, socially accepted, and does not cause immediate side effects (Hill et al, in Andea, 2010).

According to French, et al (1995, in Darani, 2013) diet is a term that includes various weight control strategies. After researchers conducted a preliminary study of 10 female students at SMAN 24 Bandung, it was found that 9 students had dissatisfaction with their body shape and had a diet. Most girls don't like any of their body shapes, namely chubby cheeks, stomach, thighs and calves. Two people cut their food consumption at night and five students admitted they didn't eat dinner. Two girls only drink milk at breakfast and two students cut back on their breakfast. The students interviewed said that they had felt dizzy, weak, and had a stomachache, including one student who had fainted and entered the UKS because she deliberately skipped breakfast to lose weight.

The diets carried out by students at SMAN 24 Bandung vary, some don't eat breakfast, don't eat dinner, take slimming pills, mayo diet, exercise and fast. Meanwhile, the results of interviews with the head of PMR at SMAN 24 Bandung said that sometimes students fainted on the grounds that they had not had breakfast and most students who entered the UKS were 
dizzy, weak, and ulcers.

\section{Literature Review}

According to French, et al (1995, in Darani, 2013) diet is a term that includes various weight control strategies. Meanwhile, in the medical dictionary Dorland (2011) states that diet is a habit in terms of the amount and type of food and drink a person eats from day to day, especially foods designed to meet specific individual needs, including or not including certain food ingredients.

According to French, Perry, Leon and Fulkerson (1995, in Darani, 2013), there are two kinds of ways to control weight, namely:

1) Healthy diet

Diet can be associated with a change in behavior towards a healthier direction, such as changing your diet by consuming low-calorie or low-fat foods. A healthy diet behavior still fulfills a person's daily nutritional needs and the weight loss that occurs is still within normal limits. A healthy diet can make a person have an ideal body without causing harmful side effects to the body. People who go on a diet for health reasons will do a healthy way too, for example following the recommended diet.

2) Unhealthy diet

This type of diet can be associated with behavior that is harmful to health, which can be done by fasting (outside of the intention of worship) or skipping meals on purpose, use of weight loss drugs, appetite suppressants, vomiting on purpose, using diet pills, diuretics, skipping breakfast, and drink diet drinks. This can cause losses in both nutritional and psychosocial intake.

Adolescent girls who are on a diet usually skip meals, the NASH survey found that $18 \%$ of young women skipped breakfast, $7 \%$ skipped lunch, and $1 \%$ skipped dinner all week Krummel (1996, in Kurnianingsih, 2010: 16). Research by Koff and Rierdan in Krowchuk (1998, in Kurnianingsih, 2010: 16) conducted on 206 young women stated that 50\% who diet skipped meals and $20 \%$ fasted.

\section{Materials and Methods}

This research uses quantitative methods with quantitative descriptive types, which describes the dietary patterns of young women at SMAN 24 Bandung. The population taken in this study were 590 female adolescents in class X, XI, and XII of SMAN 24 Kota Bandung. The sampling technique used was purposive sampling technique, it was based on the researcher's knowledge of the population that could be used as neatly selected cases included in the sample (Polit \& Beck, 2007: 257). The sample in this study were young women at SMAN 24 Bandung who met the following criteria: 1) Inclusion criteria: Inclusion criteria are general characteristics of research subjects from an affordable target population that will be studied (Nursalam, 2013: 172). The inclusion criteria in this study were: Willing to be a respondent and physically fit; 2) Exclusion criteria: Exclusion criteria eliminate or exclude subjects who meet the inclusion criteria for various reasons (Nursalam, 2013: 172). The exclusion criteria in this study were: In consultation with a doctor or nutritionist.

Measuring dietary patterns using an ordinal scale, this questionnaire uses closed questions with a Likert scale model. Calculations using WCBS proposed by French, et al (1995, in Darani, et al, 2013) were modified by researchers. The scores according to French, et al (1995) given for each answer are as follows: a) For a healthy diet: Never: 1, 1-4 times: 
2, 5-10 times: 3,> 10 times: 4, always : 5.b) For an unhealthy diet: Never: 5, 1-4 times: 4, 510 times: 3,> 10 times: 2 , always: 1

\section{Results and Discussion}

Table of Frequency Distribution of Diet Patterns in Young Women at SMAN 24 Bandung $(\mathrm{n}=86)$

Table 1. Frequency Distribution of Diet Patterns in Young Women at SMAN 24 Bandung

\begin{tabular}{ccc}
\hline Diet Patterns & Frequency & Percentage (\%) \\
\hline Healthy diet & 39 & 45,3 \\
Unhealthy diet & 47 & 54,7 \\
\hline Total & 86 & 100,0 \\
\hline
\end{tabular}

Univariate analysis of dietary patterns showed that most of the adolescent girls $(54.7 \%)$ had unhealthy diets. So it can be seen that most of the young women at SMAN 24 Bandung have an unhealthy diet.

Dietary patterns are deliberate and sustained regulation of food intake for the purpose of weight loss or weight maintenance. The univariate results on the dietary pattern variable showed that most of the respondents $(54.7 \%)$ who were studied were included in the category of unhealthy diet patterns. This is because young women want a thin body in a fast way, so they don't pay attention from the aspect of their health. Adolescent girls diet to achieve a thin body which according to them is ideal for Hill (2002, in Elaine et al, 2010).

Girls have concerns about their weight at a time when they need to be aware of any of these social pressures. Diet has become a fashionable thing, based on the belief that it is still good for one's health and improves appearance (Elaine et al, 2010). Teenage girls often do fat talk with their peers. Arroyo (2013) says that fat talk refers to negative, evaluative conversations in which women have the same opinion as each other about their bodies (for example, "I am very fat!"). These comments are often driven by negative self-evaluation and engaging in fat talk leads to negative health behaviors. Dissatisfaction with the body during adolescence is associated with a number of negative activities, especially for girls. This includes weight loss activities (Cash, 2008).

The media also has an influence on dietary patterns in adolescents, in accordance with what Utter et al said that teenage girls who frequently read magazine articles about diet and weight loss are more likely to engage in weight control behavior. Adolescents who frequently view social media have anxiety about their body image and affect their diet (Guenther, 2007: 14). The result of perceiving yourself as being overweight causes adolescents to go on a diet. Diet is a widely recognized risk factor for causing disorders in adolescence.

Research conducted by Gudnadottir (2011) states that more than half of teenage girls in high school limit their food intake in the context of a diet (Visnigdottir, 2012: 14). There is a significant gender difference in the frequency of diets. Women go on a diet more often than men. This is due to the high social pressure to become an ideal individual (Visnigdottir, 2012: 5). Factors such as fat talk with peers, the media and concerns of being overweight can influence how a teenage girl diet. 


\section{Conclusions}

Most of the young women at SMAN 24 Bandung have unhealthy diets. Community nurses can work together with educational institutions in making adolescent health programs regarding body image and dietary patterns by providing health education in the form of counseling and counseling.

\section{Acknowledgment}

Universitas Bhakti Kencana Bandung and Universitas Pendidikan Indonesia.

\section{References}

${ }^{1}$ Andea, Raisa. (2010). Hubungan antara Body Image dengan Perilaku Diet pada Utara. Remaja. Skripsi, FakultasPsikologi Universitas Sumatra http://repository.usu.ac.id/bitstream/123456789/14525/1/10E00103.pdf

${ }^{2}$ Cash,T. F \& Linda Smolak. (2011). BodyImage: A Handbook of Science,Practice, and Prevention (2th ed). New York: Guildford Press. http://books.google.co.id/books?id=bxPuCP9nCZoC\&printsec=frontc over $\& \mathrm{hl}=\mathrm{id} \# \mathrm{v}=$ onepage $\& \mathrm{q} \& \mathrm{f}=$ false,

${ }^{3}$ Cheng, Pei-Han. (2014). Racial Identity, Internalization of the DominantWhite Beauty Standards, and BodyImages among Asian AmericanWomen. Dissertation, Doctor ofPhilosophy Columbia University. New York http://eresources.pnri.go.id:2057/d ocview/1624909937/63641396EC274DA2PQ/1?accountid=25704

${ }^{4}$ Darani, Firoozeh Mustafavi, et al . (2013) Relationship of Body Satisfaction, with Nutrition and Weight Control Behaviors in Women, II 7, http://www.ncbi.nlm.nih.gov/pubm ed $/ 23671780$

${ }^{5}$ Guenther, Wendy. (2007). Media's Influence on Female College Students' Body Image and Dieting Patterns. Thesis, Department of Social

Work California State University. Long beach http://eresources.pnri.go.id:2057/do cview/304710241/B8342DC84568 557PQ/6? accountid=25704

${ }^{6}$ Huebscher, Brenda. (2010). RelationshipBetween Body Image and Self-Esteem Among Adolescent Girls.Thesis, Master of Science Degree InSchool Counseling University of Winconsin-Stout, Menomonie http://citeseerx.ist.psu.edu/viewdoc/download?doi=10.1.1.390.333\&re $\mathrm{p}=\mathrm{rep} 1 \&$ type $=\mathrm{pdf}$

${ }^{7}$ Isomaa, Rasmus. (2011). Eating Disorder, Weight Perception, and Dieting in Adolescence. Vasa: Abo AkademiUniversity https://www.doria.fi/xmlui/bitstrea $\mathrm{m} / \mathrm{handle} / 10024 / 74491 /$ isomaa_ras mus.pdf? sequence $=1$

${ }^{8}$ Jones, D. C. (2011). Interpersonal and Familial Influences on theDevelopment of Body Image. In T.

${ }^{9}$ F. Cash \& L. Smolak (Eds.), Bodyimage: A handbook of science, practice, and prevention (pp. 110- 118). NewYork: Guilford Press http://books.google.co.id/books?id=bxPuCP9nCZoC\&printsec=frontc

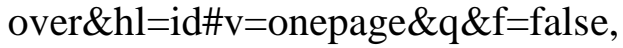

${ }^{10}$ Markey, C. N \& Markey, P. M. (2005). Relations Between Body Image andDieting Behaviors: An Examination of Gender Differences. Sex Roles,53(7/8), 519-530

${ }^{11}$ National Mental Health Institute . (2006). Eating Disorders, www.nimh.nih.gov/health/topics/e ating-disorders/index.shtml,

${ }^{12}$ Nursalam. (2013). Konsep dan Penerapan Metodologi Penelitian IlmuKeperawatan. 
Jakarta: SalembaMedika

${ }^{13}$ Papalia, E. Diana, Sally Wendkos Old \& Ruth Duskin Feldman. (2011). Human Development: Psikologi 